\title{
Cardiometabolic healthy and unhealthy obesity: does vitamin D play a role?
}

\author{
Eliana Piantanida1, *, Daniela Gallo1,*, Giovanni Veronesi ${ }^{1,2}$, Eugenia Dozio', \\ Eugenia Trotti', Adriana Lai', Silvia Ippolito', Jessica Sabatino', Maria Laura \\ Tanda', Antonio Toniolo3, Marco Ferrario ${ }^{1,2}$ and Luigi Bartalena ${ }^{1}$ \\ ${ }^{1}$ Department of Medicine and Surgery, University of Insubria, Varese, Italy \\ ${ }^{2}$ Research Center in Epidemiology and Preventive Medicine (EPIMED), University of Insubria, Varese, Italy \\ ${ }^{3}$ Department of Biotechnology and Life Science, University of Insubria, Varese, Italy \\ *(E Piantanida and D Gallo contributed equally to this work)
}

Correspondence should be addressed to E Piantanida or D Gallo Email

eliana.piantanida@ uninsubria.it or d.gallo@ uninsubria.it

\begin{abstract}
Objective: The aim of this observational study was to clarify the link between vitamin D status and metabolic syndrome (MetS) in people with visceral obesity.

Design and methods: One hundred ninety-six consecutive patients (152 women; mean age $51 \pm 13$ years) with visceral obesity (mean body weight $103 \pm 20 \mathrm{~kg}$, mean waist circumference (WC) $119 \pm 13 \mathrm{~cm}$ ) were enrolled at the Obesity Outpatient Clinic of the University of Insubria in Varese. Anthropometric measurements were recorded. Laboratory tests, including vitamin D (25(OH)D)), fasting blood glucose (FBG), lipid profile, liver and kidney function tests were assessed. Vitamin D status was defined according to the European Society of Endocrinology guidelines, MetS to the 2009 harmonized definition.

Results: An inverse association emerged among 25(OH)D, body mass index (BMI) $(P=0.001)$ and WC (all $P=0.003)$. Serum 25(OH)D levels were inversely related to FBG and systolic blood pressure (SBP) (respectively, $P=0.01$ and 0.02 ). Median serum $25(\mathrm{OH})$ D levels were $13.3 \mathrm{ng} / \mathrm{mL}(\mathrm{Cl} 95 \% 12 ; 15)$ in MetS and $16 \mathrm{ng} / \mathrm{mL}(\mathrm{Cl} 95 \% 14 ; 18)(P=0.01)$ in non-MetS patients. Among patients with MetS, lower 25(OH)D concentrations were related to higher risk of hypertension (HT) (odds ratio (OR) $1.7, \mathrm{Cl} 95 \%, 0.7 ; 4$ ) and hyperglycemia (IFG)/type 2 diabetes (OR 5.5, CI 95\% 2; 14).

Conclusion: Vitamin D status and MetS are inversely correlated in visceral obesity, particularly with regard to glucose homeostasis and BP. More extensive studies are required to investigate the potential for causality.
\end{abstract}

$\begin{aligned} & \text { Key Words } \\ & \text { - } \text { vitamin D } \\ & \text { - } \text { metabolic syndrome } \\ & \text { - diabetes } \\ & \text { - obesity }\end{aligned}$

Endocrine Connections (2017) 6, 943-951

\section{Introduction}

Dermal synthesis (90\%) and intestinal absorption (10\%) are the two main sources of vitamin $\mathrm{D}(1,2)$. In the classical pathway, serum vitamin $\mathrm{D}$ is metabolized to calcidiol $(25(\mathrm{OH}) \mathrm{D})$ in the liver and converted to its active form $1,25(\mathrm{OH})_{2} \mathrm{D}$ (or calcitriol) in the kidney (3).

Decrease in serum calcium/vitamin D concentrations directly induces the secretion of PTH that influences
$25(\mathrm{OH}) \mathrm{D}$ activation. $1,25(\mathrm{OH})_{2} \mathrm{D}$ promotes intestinal and renal absorption of calcium and acts with PTH in activating osteoclasts, promoting bone resorption and freeing calcium $(1,2,3,4,5)$. Evidence suggests that the extrarenal conversion of $25(\mathrm{OH}) \mathrm{D}$ to $1,25(\mathrm{OH})_{2} \mathrm{D}$ in numerous tissues contributes to the biological actions of vitamin D (autocrine and paracrine pathways) $(2,3,4,5)$.

$$
\begin{array}{lr}
\text { http://www.endocrineconnections.org } & \text { ○ } 2017 \text { The authors } \\
\text { DOI: } 10.1530 / \text { EC-17-0304 } & \text { Published by Bioscientifica Ltd }
\end{array}
$$


More recently, vitamin D has been implied in reducing inflammation, keeping normal resting levels of intracellular calcium and reactive oxygen radicals and preventing gene hypermethylation $(6,7,8,9)$. These mechanisms may be protective for type 2 diabetes (T2DM) development, but are defective in vitamin D deficiency $(6,10,11,12$, $13,14,15,16,17,18,19,20,21,22,23,24,25,26,27)$. The interplay between $1,25(\mathrm{OH})_{2} \mathrm{D}$ and PTH with the renin-angiotensin-aldosterone system activity (RAA) is related to myocardic hypertrophy and HT (20). Recent experiments found that $1,25(\mathrm{OH})_{2} \mathrm{D}$ induces a dose-related increase in intracellular calcium along with an increase in adipocyte fatty acid synthase and glycerol-3-phosphate dehydrogenase activities and lipolysis inhibition (28).

Metabolic syndrome (MetS) is a multifactorial condition, having central obesity as a causative factor, though the exact mechanisms remain to be elucidated $(29,30,31,32)$. Figure 1 illustrates the possible additional role of vitamin D in the development of MetS (12, 17, 18, 19, 20, 21, 22, 23, 24, 25, 26, 27, 28, 29). Polymorphisms of vitamin D receptors provide additional explanations $(12,33)$.

Obesity and vitamin D status are known to be associated, but the nature and direction of this association are controversial $(12,17,18,19,20,21,22,23,24,25$, $26,27)$. Indeed, both obesity and the obesity-related disorders may be linked to $25(\mathrm{OH}) \mathrm{D}(17,18)$. Further, two trials reported no effect of vitamin $\mathrm{D}$ supplementation on weight loss, while a small case-control trial found a beneficial significant role on fat mass reduction $(6,7,8)$.
We performed this study to observe the magnitude of correlations between $25(\mathrm{OH}) \mathrm{D}$ status and MetS in adults at higher risk for metabolic disorders.

\section{Materials and methods}

\section{Subjects}

Consecutive Caucasian obese adults with visceral obesity attending the Obesity Outpatient Clinic of the Endocrine Unite at the University of Insubria were enrolled during the years 2013-2015. All patients were Caucasian obese adults with visceral obesity $(31,32)$ and gave their informed consent to participate in the study that has been approved by the Local Ethics Committee based in Ospedale di Circolo, ASST dei Sette Laghi, Viale Borri 57, 21100, Varese, Italy.

Inclusion criteria include no concomitant supplementation with vitamin D, no evidence of psychiatric diseases, active cancer, malabsorption, type 1 diabetes, kidney failure, previous non-reversible bariatric surgery, poverty and pregnancy. Disability and cardiovascular diseases (CVD) were the main reasons for hospital admission. Patients were referred to our Clinic by Primary Care Practitioners and Specialists. Each subject was administered a questionnaire about personal habits (smoking, physical activity), comorbidities (chronic obstructive pulmonary disease, arthropathy, ischemic heart disease) and medical treatments. A second questionnaire was administered about previous attempts for weight loss (32).

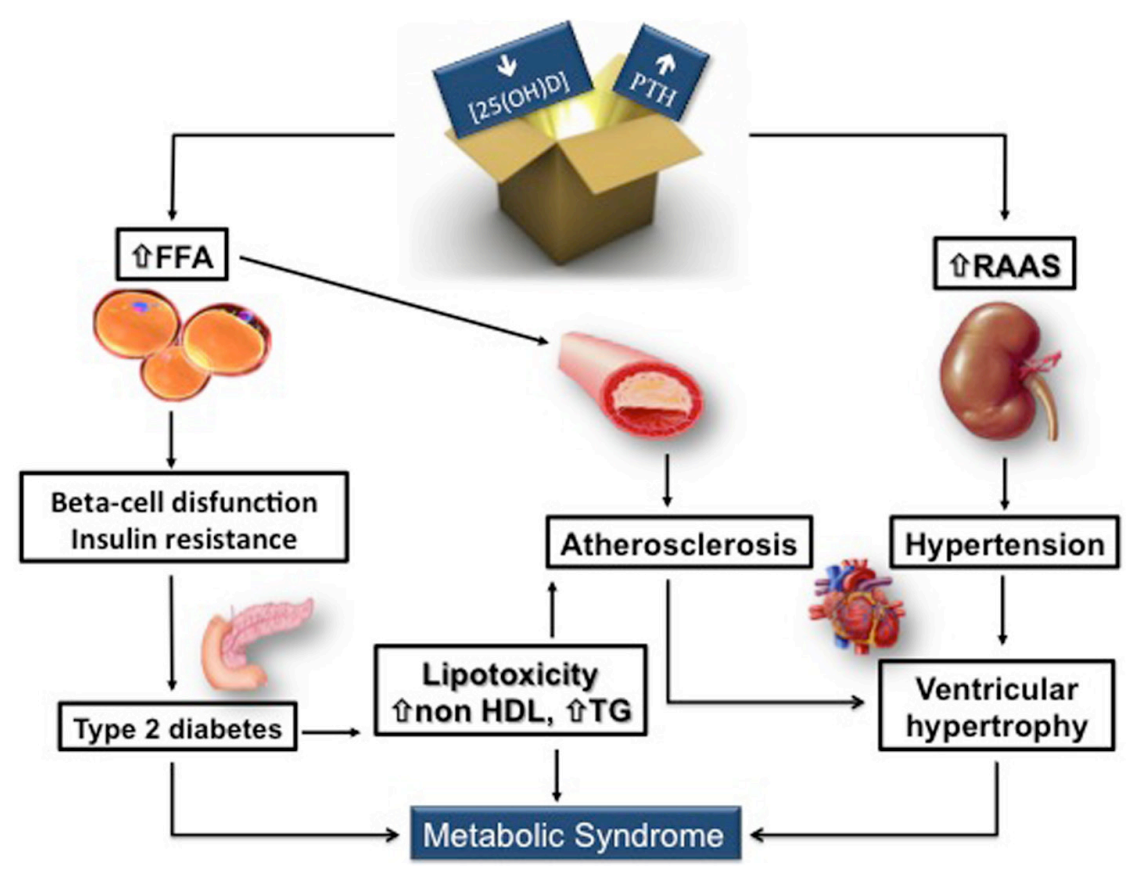

Figure 1

Possible role of vitamin D in the development of MetS.

http://www.endocrineconnections.org DOI: 10.1530/EC-17-0304 (c) 2017 The authors Published by Bioscientifica Ltd
This work is licensed under a Creative Commons Attribution-NonCommercial-NoDerivatives 4.0 International License. 


\section{Physical examination}

Body weight (100g approximation) and height $(0.5 \mathrm{~cm}$ approximation) were measured with subjects in light clothing without shoes. The body mass index (BMI) was calculated by dividing weight $(\mathrm{kg})$ by height (square meters). Obesity was classified as follows: grade I obesity for BMI $30-34.99 \mathrm{~kg} / \mathrm{m}^{2}$, grade II obesity $35-39.99 \mathrm{~kg} / \mathrm{m}^{2}$ and grade III obesity BMI $\geq 40 \mathrm{~kg} / \mathrm{m}^{2}$. To identify abdominal distribution of fat, we referred to ethnic group definition for waist circumference (WC) (male $\geq 94 \mathrm{~cm}$; female $\geq 80 \mathrm{~cm})(31,32)$.

Blood pressure (BP), approximated at $5 \mathrm{mmHg}$, was measured using calibrated sphygmomanometer with appropriate-size cuff. Heart rate was measured.

\section{Definition of MetS}

According to the 2009 harmonized definition (31), MetS was defined as the coexistence of at least 3 out of 5 risk factors, including increased WC, atherosclerotic dyslipidemia (triglycerides $\geq 150 \mathrm{mg} / \mathrm{dL}$ and/or HDL cholesterol $<40 \mathrm{mg} / \mathrm{dL}$ in men, $<50 \mathrm{mg} / \mathrm{dL}$ in women); elevated BP (SBP $\geq 130 \mathrm{mmHg}$ and/or DBP $\geq 85 \mathrm{mmHg}$ ); impaired fasting glucose (IFG) $(\geq 100 \mathrm{mg} / \mathrm{dL})$ or on-going treatment for any of the above conditions.

\section{Blood tests and vitamin D status}

Fastingvenousbloodsampleswerecollectedin 2 consecutive days, after an overnight fast, appropriate abstinence from physical activity, from smoking, alcohol and coffee. Intact parathyroid hormone (PTH): serum kept at $2-8^{\circ} \mathrm{C}$, Kit 'h-PTH 120 min-IRMA', 2-step immunoradiometric assay based on coated-tube separation, sensitivity $1 \mathrm{pg} / \mathrm{mL}$, nv 6-30 pg/mL (Scantibodies Laboratory, Santee, CA, USA). Radioimmunoassays: Insulin (Kit 'BI-INS-IRMA', based on 2 monoclonal antibodies, one radiolabelled with ${ }^{125}$ iodine and the other adsorbed onto the inner walls of the tube, sensitivity $0.1 \mu \mathrm{U} / \mathrm{mL}, \mathrm{nv}<30 \mu \mathrm{U} / \mathrm{mL}$, CisbioAssay, Codolet, France); TSH (Serum Separatur Tube, nv 0.31-4.5 U/L, DiaSorin S.p.A, Saluggia, Italy). Chemiluminescent immunoassay: quantitative determination of $25(\mathrm{OH}) \mathrm{D}$, sensitivity $1.5 \mathrm{ng} / \mathrm{mL}$, precision interval 7-11\%, Liaison 25-Vitamin D Total Assay, DiaSorin. Assay performance is unaffected by triglycerides (up to $549 \mathrm{mg} / \mathrm{dL}$ ) and cholesterolemia (up to $259 \mathrm{mg} / \mathrm{dL})(33,34,35)$.

Vitamin D status was categorized as 'severe deficiency' $\left(\mathrm{S}-\mathrm{DEF}_{\mathrm{D}}\right) \quad<10 \mathrm{ng} / \mathrm{mL} \quad 25(\mathrm{OH}) \mathrm{D}, \quad$ 'deficiency' $\left(\mathrm{DEF}_{\mathrm{D}}\right)$
10-19.9 ng/mL, 'insufficiency' (INSUF $\left.{ }_{\mathrm{D}}\right) \quad 20-29.9 \mathrm{ng} / \mathrm{mL}$ and 'sufficiency' $\left(\mathrm{SUF}_{\mathrm{D}}\right) \geq 30 \mathrm{ng} / \mathrm{mL}(3,33)$. Normal values for chemistry and hematology determinations were as follows: AST and ALT (9-36U/L), calcium (8-10 mg/dL), total cholesterol $(<200 \mathrm{mg} / \mathrm{dL}), \mathrm{HDL} \quad(>45 \mathrm{mg} / \mathrm{dL})$, triglycerides $(50-175 \mathrm{mg} / \mathrm{dL})$ and hemoglobin $\mathrm{A} 1 \mathrm{c}\left(\mathrm{HbA}_{1 \mathrm{c}}\right.$, nv $4.3-6.1 \%=23-43 \mathrm{mmol} / \mathrm{mol})$. Creatinine clearance (mL per min) was directly measured on 24 -h diuresis or calculated according to the Cockcroft-Gault equation (36). The Friedewald formula was applied to calculate LDL cholesterol (37). FPG and insulin levels were used to calculate homeostatis model analysis of insulin resistance (HOMA-IR, normal value <2.5) and beta-cell function (HOMA-B, normal value <81.7). HOMA-IR was calculated according to the formula (insulin $(\mu \mathrm{U} / \mathrm{mL}) \times$ glycemia $(\mathrm{mg} / \mathrm{dL}) / 405$ (38, 39). HOMA-B $=20 \times$ fasting insulin $(\mu \mathrm{U} / \mathrm{mL}) /($ fasting plasma glucose $(\mathrm{mg} / \mathrm{dL})-63)$ (39). The Nugent test excluded Cushing's syndrome (cortisol radioimmunoassay; normal cortisol values after $1 \mathrm{mg}$ dexamethasone suppression $<18 \mathrm{ng} / \mathrm{mL}$ ) (40).

\section{Statistical analysis}

Main demographic, clinical and laboratory parameters have been summarized as mean and standard deviation (S.D.) for continuous values, as frequency distribution for categorical features. Descriptive statistics have been estimated for all patients and categorized by $25(\mathrm{OH})$ D classes. Since only 9 obese patients were in the SUF class (5\%), a 3-category study variable $(<10,10-19.9$ and $\geq 20 \mathrm{ng} / \mathrm{mL}$ ) was taken into consideration for $25(\mathrm{OH})$ $\mathrm{D}$ values. To test the null hypothesis of no association between patients' characteristics and 25(OH)D, we reported the $P$ values from $F$-test or chi-square test, for continuous and categorical variables, respectively. Comparable analyses were performed for obesity parameters, including BMI and WC. In addition, the distribution of $25(\mathrm{OH}) \mathrm{D}$ across the range of $\mathrm{BMI}$ values is presented as box-plot (Fig. 2).

To investigate the association between MetS and $25(\mathrm{OH}) \mathrm{D}$, the OR with $95 \%$ confidence intervals of MetS were estimated for patients with $<10$ and $10-20 \mathrm{ng} / \mathrm{mL}$ of $25(\mathrm{OH}) \mathrm{D}$, using the $\geq 20 \mathrm{ng} / \mathrm{mL}$ as reference class, from a logistic model that included BMI as a covariate. Statistical analysis was expanded by using logistic regression models to estimate the association between $25(\mathrm{OH}) \mathrm{D}$ classes and each MetS component, including IR. For the statistical analyses, we used the software SAS 9.4 release (SAS Institute Inc., Cary, NC, USA). 


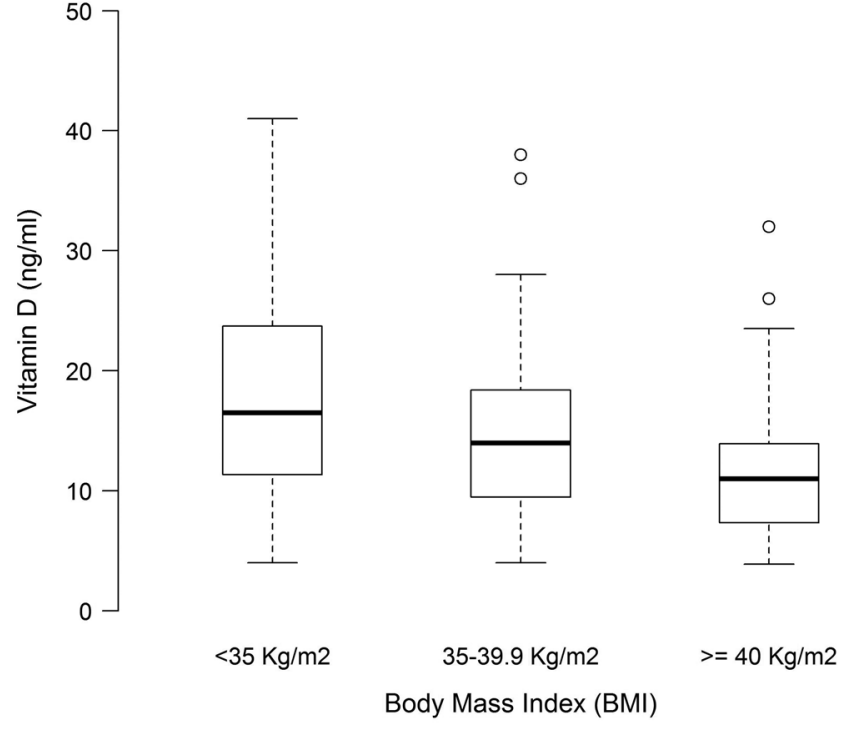

Figure 2

Distribution of serum 25(OH)D across BMI groups. Data represented as box-plot.

\section{Results}

In the study period, a cohort of 196 obese adults (152 women, $51 \pm 13$ years) fulfilled the inclusion criteria. Fifty-eight percent of patients had never participated in a lifestyle intervention program, 31\% reported a long history of weight loss attempts (either lifestyle interventions or medications), 5\% had undergone reversible bariatric surgery, $6 \%$ had recently undertaken an effective hypocaloric diet. Sedentary lifestyle was common (82\%). According to the WHO criteria (32), $26 \%$ of patients had grade I obesity, $35 \%$ grade II obesity and $39 \%$ were morbidly obese. Table 1 illustrates demographic features of the study group. No associations emerged between 25(OH)D, demographic features, personal habits, previous weight loss attempts or season of the study visit $(P=0.23)$. Over half of patients with BMI $>40 \mathrm{~kg} / \mathrm{m}^{2}$ had $\mathrm{S}-\mathrm{DEF}_{\mathrm{D}}$.

Table 2 depicts the linear negative correlation between $25(\mathrm{OH}) \mathrm{D}$ and anthropometric parameters $(P=0.0001)$ that was confirmed stratifying the population by gender and by menopausal status (data not shown). The box-plot illustrates the negative correlation with BMI.

$S-D_{D}$ and $D_{D E F}$ had markedly higher FBG (respectively, $113 \pm 39 \mathrm{mg} / \mathrm{dL}$ and $109 \pm 26 \mathrm{mg} / \mathrm{dL}$ ) than patients with $25(\mathrm{OH}) \mathrm{D} \geq 20 \mathrm{mg} / \mathrm{dL}(95 \pm 13 \mathrm{mg} / \mathrm{dL}$; F-test $P$-value for association 0.01) (Table 3). Likewise, the mean HOMA-IR was significantly higher in $\mathrm{S}^{-\mathrm{DEF}_{\mathrm{D}}}(3.6 \pm 3)$ and $\mathrm{DEF}_{\mathrm{D}}(3.8 \pm 3)$ than in the group with $25(\mathrm{OH}) \mathrm{D} \geq 20 \mathrm{ng} / \mathrm{mL}$ (2.2 $\pm 1, \quad P=0.02)$. In a preliminary analysis, the relationship between PTH and HOMA-IR failed to reach statistical significance (data not shown). Mean HOMA-B was $131 \pm 87$ (data not shown). Correlation with HOMA index was $r=0.3988$, with fasting glycemia $r=-0.362$ and with fasting insulin $r=0.64$ (data not shown). The mean HOMA-B had a similar correlation with vitamin D levels compared to HOMA index (data not shown). Mean SBP inversely correlated to 25(OH)D $(P=0.02)$, although without a linear trend. Among lipid parameters, triglycerides levels were slightly higher in $\mathrm{S}_{-} \mathrm{DEF}_{\mathrm{D}}$ than in the other vitamin D classes $(P>0.005)$ (Table 3$)$.

Association between $25(\mathrm{OH}) \mathrm{D}$ and urate, GOT, GPT and creatinine clearance failed to reach statistical significance (data not shown). Among the complications of obesity, arthropathy occurred more frequently in patients with $S-D E F_{D}$ than in other groups $(P=0.01)$ (Table 3). Patients presenting the cluster of MetS (120/196, 61\%) showed lower 25(OH)D than those not fulfilling diagnostic criteria for MetS $(13.3 \mathrm{ng} / \mathrm{mL}$, CI $95 \% 12 ; 15 ;$ vs $16 \mathrm{ng} / \mathrm{mL}$, CI 95\% $14 ; 18 \mathrm{ng} / \mathrm{mL}, P=0.01)$.

Table 1 Association between clinical features (demographic characteristics, personal habits, weight loss history) and vitamin D levels, in the study population of obese patients $(n=196)$.

\begin{tabular}{l}
\hline Vitamin D (ng/mL) \\
\hline$N$ \\
Age (s.D.) \\
Women (\%) \\
Weight loss treatments \\
$\quad$ None (\%) \\
Previous lifestyle/pharmacological intervention (\%) \\
Previous restrictive bariatric surgery (\%) \\
Current lifestyle intervention (\%) \\
Current smokers (\%) \\
Physical activity (\%)
\end{tabular}

\begin{tabular}{l}
$<\mathbf{1 0}$ \\
\hline 60 \\
$46(14)$ \\
$46(77)$ \\
$36(60)$ \\
$18(30)$ \\
$3(5)$ \\
$3(5)$ \\
$4(7)$ \\
$8(13)$
\end{tabular}

\begin{tabular}{c}
\hline $\mathbf{1 0 - 2 0}$ \\
\hline 96 \\
$51(13)$ \\
$76(79)$ \\
$59(63)$ \\
$25(27)$ \\
$5(5)$ \\
$5(5)$ \\
$10(10)$ \\
$20(21)$
\end{tabular}

\begin{tabular}{c}
\hline$\geq 20$ \\
\hline 40 \\
$50(14)$ \\
$30(75)$ \\
$19(48)$ \\
$17(43)$ \\
$1(3)$ \\
$3(8)$ \\
$8(20)$ \\
$8(20)$ \\
\hline
\end{tabular}

\begin{tabular}{c}
\hline $\boldsymbol{P}$ \\
\hline- \\
0.7 \\
0.6 \\
0.6 \\
\\
\\
\\
0.2 \\
0.5
\end{tabular}

Continuous variables are presented as mean (standard deviation, S.D.); discrete variables presented as $n(\%)$. $P$ : $P$ value(s) for overall comparisons across the study groups. 'Physical activity' includes both outdoor and indoor aerobic physical activity, practiced at least for $150 \mathrm{~min}$ for week.

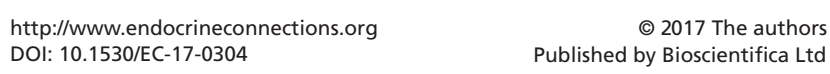


Table 2 Association between vitamin D levels and anthropometric measures.

\begin{tabular}{l}
\hline Vitamin D $(\mathrm{ng} / \mathrm{mL})$ \\
\hline$N$ \\
Mean weight (s.D.) $(\mathrm{kg})$ \\
Mean waist circumference (s.D.) (cm) \\
Mean BMI (s.D.) $\left(\mathrm{kg} / \mathrm{m}^{2}\right)$ \\
BMI classes $(\%)$ \\
$\mathrm{BMI}<35 \mathrm{~kg} / \mathrm{m}^{2}$ \\
$\mathrm{BMI}<40 \mathrm{~kg} / \mathrm{m}^{2}$ \\
$\mathrm{BMI} \geq 40 \mathrm{~kg} / \mathrm{m}^{2}$
\end{tabular}

\begin{tabular}{c}
\hline$<\mathbf{1 0}$ \\
\hline 60 \\
$108.1(21)$ \\
$124.2(13)$ \\
$41.8(7)$
\end{tabular}

\begin{tabular}{c}
\hline $\mathbf{1 0 - 2 0}$ \\
\hline 96 \\
$102.7(20)$ \\
$118.2(12)$ \\
$39.3(6)$
\end{tabular}

\begin{tabular}{c}
$\geq \mathbf{2 0}$ \\
\hline 40 \\
$96.1(15)$ \\
$114.5(11)$ \\
$36.3(4)$
\end{tabular}

\begin{tabular}{c}
\hline $\boldsymbol{P}$ \\
\hline- \\
0.01 \\
0.0003 \\
0.0001
\end{tabular}

\begin{tabular}{c}
\hline${ }^{* \boldsymbol{P}}$ \\
\hline- \\
0.08 \\
0.003 \\
0.01
\end{tabular}

\begin{tabular}{l}
\hline$* \boldsymbol{P}$ \\
\hline- \\
0.07 \\
0.1 \\
0.005
\end{tabular}

$9(15 \%)$
$20(33 \%)$
$31(52 \%)$

$25(26 \%)$
$33(34 \%)$
$38(40 \%)$

$18(45 \%)$

$16(40 \%)$

0.002

0.2

0.01

Continuous variables are presented as mean (standard deviation, S.D.); discrete variables presented as $n$ (\%). Waist circumference was approximated at $1 \mathrm{~cm}$, weight at $100 \mathrm{~g}$ and height (in BMI formula) at $0.5 \mathrm{~cm}$. P value(s) for overall comparisons across the study groups ( $F$-test and chi-square test for continuous and discrete variables, respectively) and for testing pairwise comparisons (*vitamin D $<10 \mathrm{ng} / \mathrm{mL}$ vs $10-20 \mathrm{ng} / \mathrm{mL} ; * * 10-20 \mathrm{ng} / \mathrm{mL} v \mathrm{vs} \geq 20 \mathrm{ng} / \mathrm{mL}$ ) whenever the overall test was statistically significant.

Interestingly, 25(OH)D averaged $21 \mathrm{ng} / \mathrm{mL}$ (CI 95\% 18; $24 \mathrm{ng} / \mathrm{mL}$ ) in isolated obesity, decreasing to $13.7 \mathrm{ng} / \mathrm{mL}$ (CI 95\% 11; 16ng/mL) when all 5 MetS components were present $(P=0.001)$. IFG/T2DM occurred more frequently in deficiency $(65 \%)$ than when $25(\mathrm{OH}) \mathrm{D}$ was $\geq 20 \mathrm{ng} / \mathrm{mL}$ (25\%, $P=0.0002$ ) (Supplementary material, see section on supplementary data given at the end of this article). HT had a similar trend $(P=0.01)$, whereas the prevalence of HTG was just slightly different among vitamin D classes, a trend emerged for low HDL dyslipidemia. Compared to the reference category, the OR of IFG/T2DM revealed a significant risk for vitamin D-deficient subjects $\left(\mathrm{S}_{-} \mathrm{DEF}_{\mathrm{D}} 5.5, \mathrm{CI} 95 \% 2 ; 14 ; \mathrm{DEF}_{\mathrm{D}}\right.$ 5.4 CI 95\% 2; 13). Figure 3 shows how the risks for HT $\left(\mathrm{S}-\mathrm{DEF}_{\mathrm{D}}\right.$ 1.65, CI 95\% 0.7;4; $\mathrm{DEF}_{\mathrm{D}} 3.2$, CI 95\% 1.5;7) and MetS $\left(\mathrm{S}_{-\mathrm{DEF}}\right.$ 1.8, CI 95\% 0.8;4 and $\mathrm{DEF}_{\mathrm{D}} 3.3$, CI 95\% $1.5 ; 7)$ were higher in $25(\mathrm{OH}) \mathrm{D}$ deficiency compared to reference.

Table 3 Association between main laboratory characteristics and obesity-related comorbidities with vitamin D levels, in the study population of obese patients $(n=196)$.

\begin{tabular}{l} 
Vitamin D (ng/mL) \\
\hline Glycemic profile \\
Mean fasting glycemia (s.D.) (mg/dL) \\
Mean HOMA-IR (s.D.) \\
Treatment for diabetes (\%) \\
Blood pressure \\
Mean SBP (s.D.) (mmHg) \\
Mean DBP (s.D.) (mmHg) \\
Antihypertensive treatment (\%) \\
Lipid profile \\
Mean total cholesterol (mg/dL) \\
Mean HDL (s.D.) (mg/dL) \\
Mean LDL (s.D.) (mg/dL) \\
Mean TG (s.D.) (mg/dL) \\
Lipid lowering treatment (\%) \\
Comorbidities and uricemia (\%) \\
Ischemic cardiopathy \\
Artropathy \\
COPD \\
Uricemia^ (mg/dL) \\
Other medications (\%) \\
Levothyroxine \\
Allopurinol \\
Mean TSH levels (s.D.) (U/L)
\end{tabular}

\begin{tabular}{|c|c|}
\hline$<10$ & $10-20$ \\
\hline 113 (39) & 109 (26) \\
\hline $3.6(3)$ & $3.8(3)$ \\
\hline $14(23 \%)$ & $14(15 \%)$ \\
\hline 131 (14) & 135 (12) \\
\hline $80(8)$ & $82(11)$ \\
\hline $31(52 \%)$ & $44(46 \%)$ \\
\hline $202(36)$ & $210(40)$ \\
\hline $51(12)$ & 52 (13) \\
\hline $123(32)$ & $131(36)$ \\
\hline $142(74)$ & $134(59)$ \\
\hline $17(28 \%)$ & $28(29 \%)$ \\
\hline $6(10 \%)$ & $11(12 \%)$ \\
\hline $28(48 \%)$ & $24(25 \%)$ \\
\hline $35(19 \%)$ & $29(20 \%)$ \\
\hline $5.6(1)$ & $5.6(1)$ \\
\hline $10(17.2 \%)$ & $19(21.1 \%)$ \\
\hline $8(13.3 \%)$ & $3(3.1 \%)$ \\
\hline $2.4(2)$ & $3(9)$ \\
\hline
\end{tabular}

\begin{tabular}{c}
\hline$\geq 20$ \\
\hline $95(13)$ \\
$2.2(1)$ \\
$3(8 \%)$ \\
$129(10)$ \\
$80.6(5)$ \\
$15(38 \%)$ \\
$213(32)$ \\
$53(12)$ \\
$131(31)$ \\
$134(59)$ \\
$9(23 \%)$ \\
$3(8 \%)$ \\
$11(28 \%)$ \\
$6(16 \%)$ \\
$5.5(2)$ \\
$8(23.5 \%)$ \\
$3(7.5 \%)$ \\
$2.4(2)$ \\
\end{tabular}

\begin{tabular}{ll}
\hline \multicolumn{1}{c}{$\boldsymbol{P}$} \\
\hline \\
0.01 \\
0.02 \\
0.09 \\
\\
0.02 \\
0.4 \\
0.4 \\
\\
0.3 \\
0.3 \\
0.3 \\
0.7 \\
0.7 \\
\\
0.8 \\
0.01 \\
0.6 \\
1.0 \\
\\
0.7 \\
0.055 \\
0.7 \\
\hline
\end{tabular}

\begin{tabular}{c}
\hline${ }^{*} \boldsymbol{P}$ \\
\hline \\
0.4 \\
0.7 \\
-
\end{tabular}

\begin{tabular}{l}
\hline${ }^{* * \boldsymbol{P}}$ \\
\hline 0.01 \\
0.006 \\
-
\end{tabular}

0.04

0.008

$-\quad-$

Continuous variables are presented as mean (standard deviation, s.D.); discrete variables are presented as $n$ (\%). $P$ : $P$-value(s) for overall comparisons across the study groups ( $F$-test and chi-square test for continuous and discrete variables, respectively) and for testing pairwise comparisons (*vitamin $D$ $<10 \mathrm{ng} / \mathrm{mL}$ vs $10-20 \mathrm{ng} / \mathrm{mL} ; * * 10-20 \mathrm{ng} / \mathrm{mL}$ vs $\geq 20 \mathrm{ng} / \mathrm{mL}$ ) whenever the overall test was statistically significant. Data available for ${ }^{\circ} 172$ cases and for ${ }^{\wedge} 160$ cases.

COPD, chronic obstructive pulmonary disease.

$\begin{array}{lr}\text { http://www.endocrineconnections.org } & \text { ○ } 2017 \text { The authors } \\ \text { DOI: } 10.1530 / \text { EC-17-0304 } & \text { Published by Bioscientifica Ltd }\end{array}$


A

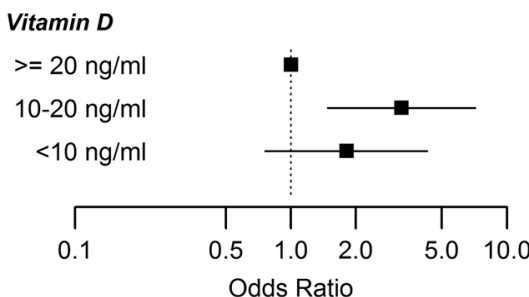

C

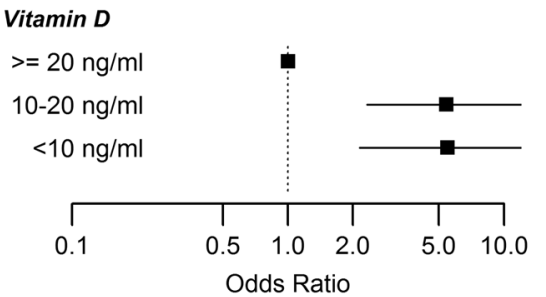

\section{Vitamin D}

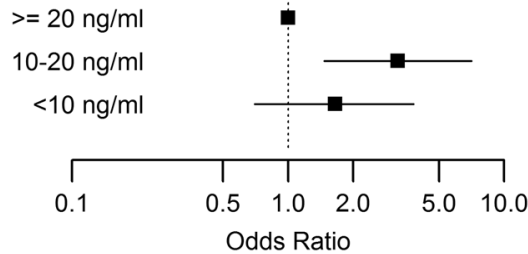

D

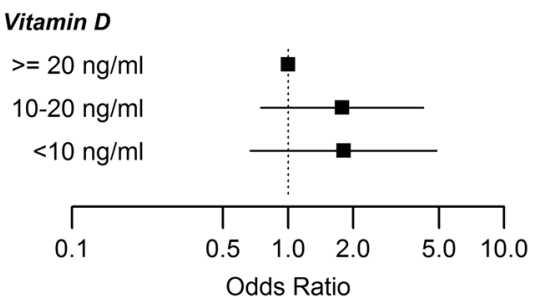

Hypertension

\section{Figure 3}

OR (Cl 95\%) of MetS (A) and its components (B-D) for $D_{E F}$ and S- $D_{D F}$, using 25(OH)D $\geq 20 \mathrm{ng} / \mathrm{mL}$ as reference class, from a logistic model, including BMI as covariate.

\section{Discussion}

The relationship between 25(OH)D levels and cardiometabolic morbidities in metabolically healthy and unhealthy obesity was studied. Serum $25(\mathrm{OH}) \mathrm{D}$ concentration is widely considered the best indicator for vitamin $D$ reserve, reflecting both diet intake and exposure to UV radiation $(3,7)$. Relatively high variability in $25(\mathrm{OH})$ $\mathrm{D}$ can be problematic when comparing concentrations across studies $(19,20,21)$. The Liaison assay has been validated by several groups as an appropriate measurement method $(33,34,35)$.

According to recent reports, an increase of $1 \mathrm{~kg} / \mathrm{m}^{2}$ of BMI is associated with $1.15 \%$ reduction in serum $25(\mathrm{OH})$ D $(13,14,15,16)$. In this study, 25(OH)D, BMI and WC were inversely correlated. Cardiometabolic parameters such as IFG, T2DM and HOMA-IR showed the same trend.

The regulating role of vitamin $\mathrm{D}$ on insulin secretion is a possible explanation $(19,20,21,22,23,24,25,26$, $27,41)$. Nevertheless, vitamin D may have a restricted effect in the early phase of beta-cell damage, explaining the failure of intervention studies $(43,44)$. Additionally, abnormalities of vascular smooth cells mediated both by insulin resistance and by the RAA $(8,9)$ may contribute to the elevated SBP identified.

It recently appears that people with $25(\mathrm{OH}) \mathrm{D}$ $<10 \mathrm{ng} / \mathrm{mL}$ have higher risk for chronic diseases than those with $25(\mathrm{OH}) \mathrm{D} \geq 20 \mathrm{ng} / \mathrm{mL}$ and even more if compared to those with $25(\mathrm{OH}) \mathrm{D} \geq 30 \mathrm{ng} / \mathrm{mL}$ (21). The most recent data from randomized clinical trials on CVD state that serum $25(\mathrm{OH}) \mathrm{D} \geq 20 \mathrm{ng} / \mathrm{mL}$ are sufficient to meet the requirements of $97.5 \%$ of the population (21).
In this study, the OR analysis of MetS, its components and IR demonstrated that patients with 25(OH)D $<20 \mathrm{ng} / \mathrm{mL}$ had increased risk for IFG/T2DM, HT and MetS. The risk for IFG/T2FM had a slight correlation with the severity of $25(\mathrm{OH}) \mathrm{D}$ deficiency, suggesting a central role of insulin and glucose metabolism. The PROspective study involving a non-diabetic population demonstrated an increased risk to develop glycemic disorders over a 10-year time $(18,44)$. In the current study, the lack of a linear trend for HT prevalence-vitamin D relationship, even by excluding patients being treated for HT, influenced the trend for MetS.

Recently, the concomitant deficiency of magnesium and vitamin $\mathrm{D}$ in obesity has been associated with an increased risk of cardiometabolic disease $(45,46)$.

A multivariate analysis involving analysis of demographic and anthropometric data and personal habits could better clarify this point.

The Australian Diabetes, Obesity and Lifestyle Study reported that, among risk factors, BMI was conditioning MetS occurrence more than vitamin D levels (24). Because our results were confirmed after adjusting for BMI, we suggest an independent relevant role of vitamin D levels. At variance from previous studies (17), a significant correlation between $25(\mathrm{OH}) \mathrm{D}$ and lipid profile could not be detected. However, even if not significant, the OR for low HDL was in positive correlation with 25(OH)D. The fact that the data of the literature only report small variations in cholesterol levels in $\mathrm{DEF}_{\mathrm{D}}$ may explain the results $(8,47)$.

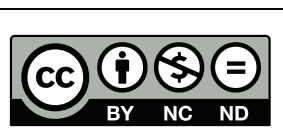

This work is licensed under a Creative Commons Attribution-NonCommercial-NoDerivatives 4.0 International License. 
The potential strengths and limitations of this study deserve considerations. First, the cross-sectional design does not allow defining a causality link. Secondly, due to the low prevalence of patients with optimal $25(\mathrm{OH}) \mathrm{D}$, a larger sample size would have been required to adequately assess the parameters of obese patients in the right tail of the $25(\mathrm{OH}) \mathrm{D}$ distribution. Although vitamin D classes were well balanced with respect to major demographic and clinical characteristics that may interfere with $25(\mathrm{OH}) \mathrm{D}$ and fat distribution, including comorbidities, physical activity and smoking habits, the presence of residual confounders cannot be ruled out. The main strength is the uniformity of the investigated cohort. To our knowledge, this is the first study selecting Caucasian adults at higher risk of metabolic morbidities. This may provide homogeneity in results, given for instance the different bioavailability of vitamin D in blacks compared to whites, as well as in fat storage (48). Previous studies on this topic differ in methodology and population; thus, evidence remains inconclusive (17).

Other strengths were the centralization of all tests and the direct assessment of patients, evaluated by a single trained team. Moreover, the survey considered comorbidities, such as arthropathy, ischemic heart disease and pulmonary diseases possibly responsible for reverse causality effect (severely ill patients could have low vitamin $\mathrm{D}$ for shorter exposure to sun rather than the other way around) (14).

In conclusion, the results of this original observational study confirm a significant inverse association of vitamin D status and MetS. For instance, vitamin D deficiency might represent one of the environmental factors in the pathogenesis and progression of T2DM, obesity and MetS. A detailed metabolic phenotyping could support more qualified intervention programs and detect patients at higher risk for metabolic disorders $(20,23,30,31,46$, 47, 48, 49).

Vitamin D supplementations proposed to prevent and correct the well-established bone consequences of 25(OH)D deficiency, in addition to lifestyle intervention programs, may be helpful to prevent the progression of metabolic disorders (19). Prospective data on the effect of vitamin D supplementation in these patients will be collected and analyzed. Consistent evidences from large, randomized, placebo-control trials with adequate statistic power and eventually exploring the association of vitamin $\mathrm{D}$ and other nutritional elements (46) are warranted to confirm these findings.

\section{Supplementary data}

This is linked to the online version of the paper at http://dx.doi.org/10.1530/ EC-17-0304.

\section{Declaration of interest}

The authors declare that there is no conflict of interest that could be perceived as prejudicing the impartiality of the research reported.

\section{Funding}

Daniela Gallo was supported by a University of Insubria PhD scholarship. Statistical analysis was performed by Giovanni Veronesi.

\section{Compliance with ethical standards}

The study has been approved by the Ethics Committee of the Ospedale di Circolo, Varese, Italy. Informed consent has been obtained from all subjects before enrollment.

\section{References}

1 Holick M. Vitamin D deficiency. New England Journal of Medicine 2007 357 266-281. (doi:10.1056/NEJMra070553)

2 Cianferotti L \& Marcocci C. Subclinical vitamin D deficiency. Best Practice and Research Clinical Endocrinology and Metabolism 201226 523-537. (doi:10.1016/j.beem.2011.12.007)

3 Holick MF, Binkley NC, Bischoff-Ferrari HA, Gordon CM, Hanley DA, Heaney RP, Murad MH, Weaver CM \& Endocrine Society. Evaluation, treatment, and prevention of vitamin D deficiency: an Endocrine Society clinical practice guideline. Journal of Clinical Endocrinology and Metabolism 201196 1911-1930. (doi:10.1210/jc.2011-0385)

4 Gröber U, Spitz J, Reichrath J, Kisters K \& Holick MF. Vitamin D: update 2013: from rickets prophylaxis to general preventive healthcare. Dermato-Endocrinology 20135 331-347. (doi:10.4161/ derm.26738)

5 Holick MF. The vitamin D deficiency pandemic: a forgotten hormone important for health. Public Health Reviews 32 267. (doi:10.1007/ BF033916029)

6 Autier P \& Gandini S. Vitamin D supplementation and total mortality: a meta-analysis of randomized controlled trials. Archives of Internal Medicine 2007167 1730-1737. (doi:10.1001/ archinte.167.16.1730)

7 Holick MF. The vitamin D deficiency pandemic. Public Health Reviews 201032 267-283. (doi:10.1007/BF03391602)

8 Jorde R \& Grimes G. Vitamin D and metabolic health with special reference to the effect of vitamin D on serum lipids. Progress in Lipid Research 201150 303-312. (doi:10.1016/j.plipres.2011.05.001)

9 Makariou S, Liberopoulos E, Elif M \& Challa A. Novel roles of vitamin D in disease: what in new in 2011? European Journal of Internal Medicine 201122 355-362. (doi:10.1016/j.ejim.2011.04.012)

10 SalekZamani S, Mehralizadeh H, SalekZamani Y, Jafarabadi MA, Bavil AS \& Gargari BP. Effect of hight-dose vitamin D supplementation on cardiometabolic risk factors in subjects with metabolic syndrome: a randomized controlled double blind clinical trial. Journal of Endocrinology Investigation 201639 1303-1313. (doi:10.1007/s40618-016-0507-8)

11 Al-Daghri NM, Aljohani N, Rahman S, Sabico S, Al-Attas OS, Alokail MS, Al-Ajlan A \& Chrousos GP. Serum 25-hydroxyvitamin D status among Saudi children with and without a history of fracture. Journal of Endocrinological Investigation 201639 1125-1130. (doi:10.1007/s40618-016-0496-7)

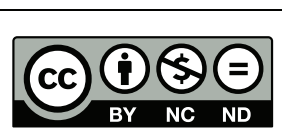

This work is licensed under a Creative Commons Attribution-NonCommercial-NoDerivatives 4.0 International License. 
12 Berridge MJ. Vitamin D deficiency and diabetes. Biochemical Journal 2017474 1321-1332. (doi:10.1042/BCJ20170042)

13 Blum M, Dolnikowski G, Seyoum E, Harris SS, Booth SL, Peterson J, Saltzman E \& Dawson-Hughes B. Vitamin $\mathrm{D}_{3}$ in fat tissue. Endocrine 200833 90-94. (doi:10.1007/s12020-008-9051-4)

14 Salehpour A, Hossein Panahi F, Shadfar F, Vafa M, Razani M, Dehghani S, Hoshiarrad A \& Gohari M. A 12-week double-blind randomized clinical trial of vitamin $\mathrm{D}_{3}$ supplementation on body fat mass in healthy overweight and obese women. Journal of Nutrition 201211 78-96. (doi:10.1186/1475-2891-11-78)

15 Wortsman J, Matsuoka L, Chen TC, Zhiren L \& Holick M. Decreased bioavailability of vitamin D in obesity. American Journal of Clinical Nutrition 200072 690-693.

16 Bell NH, Epstein S, Greene A, Sharyn J \& Oexmann MJ. Evidence for an alteration of the vitamin D-endocrine system in obese subjects. Journal of Clinical Investigation 198576 370-373. (doi:10.1172/ JCI111971)

17 Vitezova A, Zillikens MC, van Herpt TT, Sijbrands EJ, Hofman A Uitterlinden AG, Franco OH \& Kiefte-de Jong JC. Vitamin D status and metabolic syndrome in the elderly: the Rotterdam study. European Journal of Endocrinology 2015172 327-335. (doi:10.1530/ EJE-14-0580)

18 Beydoun M, Boueiz A, Shroff MR, Beydoun H, Wang Y \& Zonderman B. Associations among 25-hydroxyvitamin D, diet quality, and metabolic disturbance differ by adiposity in adults in the United States. Journal of Clinical Endocrinology and Metabolism 2010 95 3814-3827. (doi:10.1210/jc.2010-0410)

19 Khan H, Kunutsor S, Franco OH \& Chowdhury R. Vitamin D, type 2 diabetes and other metabolic outcomes: a systematic review and meta-analysis of prospective studies. Proceedings of the Nutrition Society 201372 89-97. (doi:10.1017/S0029665112002765)

20 Prasa P \& Kochar A. Interplay of vitamin D and metabolic syndrome: a review. Clinical Research Review 201610 105-112. (doi:10.1016/j. dsx.2015.02.014)

21 Muscogiuri G, Altieri B, Annweiler C, Balercia G, Pal HB, Boucher BJ, Cannel JJ, Forest C, Grubler MR, Kotsa K, et al. Vitamin D and chronic diseases: the current state of the art. Archives of Toxicology 201691 97-101. (doi:10.1007/s00204-016-1804-x)

22 Bischoff-Ferrari HA, Giovannucci E, Willett WC, Dietrich T \& Dawson-Hughes B. Estimation of optimal serum concentrations of 25-hydroxyvitamin D for multiple health outcomes. American Journal of Clinical Nutrition 200684 18-28.

23 Srikanthan K, Feyh A, Visweshwar H, Shapiro JI \& Sodhi K. Systematic review of metabolic syndrome biomarkers: a panel for early detection, management, and risk stratification in the West Virginian population. International Journal of Medical Sciences 201613 25-38. (doi:10.7150/ijms.13800)

24 Gagnon C, Lu ZX, Magliano DJ, Dunstan DW, Shaw JE, Zimmet PZ, Sikaris K, Ebeling PR \& Daly RM. Low serum 25-OH vitamin D is associated with increased risk of the development of the metabolic syndrome at five years: results form a national, population-based prospective study. Journal of Clinical Endocrinology and Metabolism 201297 1953-1961. (doi:10.1210/jc.2011-3187)

25 Muscogiuri G, Sorice GP, Prioletta A, Policola C, Della Casa S, Pontecorvi A \& Giaccari A. 25-Hydroxyvitamin D concentration correlates with insulin-sensitivity and BMI in obesity. Obesity 2010 18 1906-1910. (doi:10.1038/oby.2010.11)

26 Cheng S, Massaro JM, Fox CS, Larson MG, Keyes MJ, McCabe EL, Robins, SJ, O’Donnell CJ, Hoffmann U, Jacques PF, et al. Adiposity, cardiometabolic risk, and vitamin D status: the Framingham Heart Study. Diabetes 201059 242-248. (doi:10.2337/db09-1011)

27 Forouhi NG, Luan J, Cooper A, Voucher BJ \& Wareham N. Baseline serum $25-\mathrm{OH}$ vitamin $\mathrm{D}$ is predictive of future glicemic status and insulin resistance (the medical research council Ely Prospective Study 1990-2000). Diabetes 200857 2619-2625. (doi:10.2337/db08-0593)

http://www.endocrineconnections.org DOI: 10.1530/EC-17-0304
28 Parikh SJ, Edelman M, Uwaifo GI, Freedman RJ, Semega-Janneh M, Reynolds J \& Yanovski KA. The relationship between obesity and serum 1,25-dihydoxy vitamin D concentrations in healthy adults. Journal of Clinical Endocrinology and Metabolism 200489 1196-1199. (doi:10.1210/jc.2003-031398)

29 Agbaht K, Mercan Y, Kutlu S, Alpdemir M \& Sezgin T. Obesity with and without metabolic syndrome: do vitamin D and thyroid autoimmunity have a role? Diabetes Research and Clinical Practice 2014106 27-34. (doi:10.1016/j.diabres.2014.08.001)

30 Cameron AJ, Dunstan DW, Owen N, Zimmet PZ, Barr EL, Tonkin AM, Wilborn TA \& Shaw JE. Health and mortality consequences of abdominal obesity: evidence from the AusDiab study. Medicine Journal Australia 2009191 202-208.

31 Alberti KGM, Eckel RH, Grundy SM, Zimmet PZ, Cleeman JI, Donato KA, Fruchart J-C, James WPT, Loria CM \& Smith SC Jr. Harmonizing the metabolic syndrome: a joint interim statement of the International Diabetes Federation Task Force on Epidemiology and Prevention; National Heart, Lung, and Blood Institute; American Heart Association; World Heart Federation; International Atherosclerosis Society and International Society for the Study of Obesity. Circulation 2009120 1640-1645. (doi:10.1161/ CIRCULATIONAHA.109.192644)

32 Expert Panel Members, Jensen MD, Ryan DH, Donato KA, Apovian CM, Jamy D, Comuzzie AG, Hu FB, Van Hubbard S, Jakicic JM, et al. Executive summary: guidelines (2013) for the management of overweight and obesity in adults. Obesity 201422 S5-S39. (doi:10.1002/oby.20821)

33 Pludowski P, Holick MF, Grant WB, Konstantynowicz J, Mascarenhas MR, Haq A, Povoronznyuk V, Balatska N, Misiorowski W, Zakharava I, et al. Vitamin D supplementation guidelines. Journal Steroid Biochemical and Molecular Biology 2017 [in press]. (doi:10.1016/j.jsbmb.2017.01.021)

34 Bianchi S, Maffei S, Prontera C, Battaglia D \& Vassalle C. Preanalytical, analytical (DiaSorin LIAISON) and clinical variables potentially affecting the $25-\mathrm{OH}$ vitamin $\mathrm{D}$ estimation. Clinical Biochemistry 201245 1652-1657. (doi:10.1016/j. clinbiochem.2012.08.003)

35 Freeman J, Wilson K, Spears R, Shalhoub V \& Sibley P. Performance evaluation of four 25-hydorixyvitamin-D assays to measure 25-hydroxyvitamin $\mathrm{D}_{2}$. Clinical Biochemistry 201548 1097-1104. (doi:10.1016/j.clinbiochem.2015.05.021)

36 Lin J, Knight EL, Hogan ML \& Singh AK. A comparison of prediction equations for estimating glomerular filtration rate in adults without kidney disease. Journal of American Society of Nephrology 200314 2573-2580. (doi:10.1097/01.ASN.0000088721.98173.4B)

37 Tremblay AJ, Morrissette H, Gagné JM, Bergeron J, Gagné C \& Couture P. Validation of the Friedewald formula for the determination of low-density lipoprotein cholesterol compared with beta-quantification in a large population. Clinical Biochemistry 2004 37 785-790. (doi:10.1016/j.clinbiochem.2004.03.008)

38 Matthews DR, Hosker JP, Rudenski AS, Naylor BA, Treacher DF \& Turner R. Homeostasis model assessment: insulin resistance and betacell function from fasting plasma glucose and insulin concentrations in man. Diabetologia 198528 412-419. (doi:10.1007/BF00280883)

39 Yang Y, Zhang X, Bao M, Liu L, Xian Y, Wu J \& Li P. Effect of serum 25-hydroxyvitamin D3 on insulin resistance and beta-cell function in newly diagnosed type 2 diabetes patients. Journal of Diabetes Investigation 20167 226-232. (doi:10.1111/jdi.12381)

40 Nieman LK, Biller MBK, Findling JW, Newell-Price J, Savage MO, Stewart PM \& Montori VM. The diagnosis of Cushing's syndrome: an Endocrine Society Clinical Practice Guideline. Journal of Clinical Endocrinology and Metabolism 200893 1526-1540. (doi:10.1210/ jc.2008-0125)

41 Pittas A, Lau J, Jhu FB \& Dawson-Hughes B. The role of vitamin $\mathrm{D}$ and calcium in type 2 diabetes. A systematic review and meta-
() 2017 The authors Published by Bioscientifica Ltd
This work is licensed under a Creative Commons Attribution-NonCommercial-NoDerivatives 4.0 International License. 
analysis. Journal of Clinical Endocrinology 200792 2017-2029. (doi:10.1210/jc.2007-0298)

42 Peterson C, Tosh A \& Belenchia A. Vitamin D insufficiency and insulin resistance in obese adolescents. Therapeutic Advances in Endocrinology and Metabolism 20145 166-189. (doi:10.1177/2042018814547205)

43 Chagas C, Borges M, Martini L \& Rogero M. Focus on vitamin D, inflammation and type 2 diabetes. Nutrients 20124 52-57. (doi:10.3390/nu4010052)

44 George P, Pearson E \& Witham M. Effect of vitamin D supplementation on glycaemic control and insulin resistance: a systematic review and meta-analysis. Diabetes Medicine 201229 e142-e150. (doi:10.1111/j.1464-5491.2012.03672.x)

45 Stokic E, Kupusinac A, Tomic'-Naglic' D, Zavisic' BK, Mitrovic' M, Smiljenic' D, Soskic' S \& Isenovic' E. Obesity and vitamin D deficiency: trends to promote a more proatherogenic cardiometabolic risk profile. Angiology 201566 237-243. (doi:10.1177/0003319714528569)
46 Stokic E, Romani A, Llincic B, Kupusinac A, Stsic Z \& Isenovic ER. Chronic latent magnesium deficiency in obesity decreases positive effects on vitamin D and cardiometabolic risk indicators. Current Vascular Pharmacology 2017 [in press]. (doi:10.2174/15701611156661 70821154841)

47 Parker J, Hashmi O, Dutton D, Mavrodaris A, Strange S \& Kandala NB. Levels of vitamin D and cardiometabolic disorders: systematic review and meta-analysis. Maturitas 201065 225-236. (doi:10.1016/j.maturitas.2009.12.013)

48 Holick MF. Bioavaibility of vitamin D and its metabolites in black and white adults. New England Journal of Medicine 2013369 2047-2048. (doi:10.1056/NEJMe1312291)

49 Muscogiuri G, Sorice GP, Ajjan R, Mezza T, Pilz S, Prioletta A, Scragg R, Volpe SL, Witham MD \& Giaccari A. Can vitamin D deficiency cause diabetes and cardiovascular diseases? Present evidence and future perspectives. Nutrition, Metabolism and Cardiovascular Diseases 201222 81-87. (doi:10.1016/j. numecd.2011.11.001)

Received in final form 17 October 2017

Accepted 31 October 2017

Accepted Preprint published online 31 October 2017 